\title{
FINES AND DAILY FINES UNDER THE ACT ON THE AMENDMENTS TO COMPETITION ACT WITH SPECIAL EMPHASIS ON MITIGATING AND AGGRAVATING CIRCUMSTANCES
}

\author{
Tena Konjević, Student \\ Josip Juraj Strossmayer University of Osijek, Faculty of Law Osijek \\ Grbavica 35, 35000 Slavonski Brod, Croatia \\ konjevic.tena@gmail.com
}

\begin{abstract}
The paper analyzes the amendments to Title VIII of the Croatian Competition Act regulating penalty clause or the fines, daily fines, and the methods for their imposition, adopted in April 2021. Daily fines are a new institute that further extends the Croatian Competition Agency's (CCA) power as a general, national regulatory authority responsible for the protection of competition in all markets. Therefore, each amended article of that Title is analysed to accurately reflect what has changed and with which provision of the Directive (EU) 2019/1 it has been harmonized. The paper also provides a detailed tabular overview and comparison of the amount of the fine and mitigating and aggravating circumstances that the Agency considered into account when imposing them in cases in the period from 2013 to the end of 2020, so that, finally, it can be concluded if there is a consistent relationship between the number of mitigating and aggravating circumstances and the amount of the fine that CCA imposes when there are infringements of the national and EU competition law.
\end{abstract}

Keywords: Competition Act, Amendment, fines, daily fines, mitigating and aggravating circumstances

\section{INTRODUCTION}

The amendments to the Title VIII of the Competition Act $^{1}$ (hereafter 'CA'), which regulates the penalty clause or the fines, daily fines, and mitigating and aggravating circumstances for their imposition, will be analysed below. However, to be able to talk about fines and how they are imposed, as well as amendments in the

The Competition Act, Official Gazette No. 79/09, 80/13, 41/21 
CA regarding fines and the introduction of daily fines, it is first necessary to say something about the authority that imposes them.

"The Commission shares with the national authorities the power to rule upon the admissibility of agreements, decisions and concerted practices and abuses of a dominant position (Arts 104-105 TFEU)“, therefore, the European Commission is working closely with the national competition authorities on the application of the European competition law. ${ }^{2}$ To the national authorities to be considered competent to decide in a particular case, there must be a material link between the infringement and the territory in which the infringement was committed. ${ }^{3}$

Based on the above considerations, points should be noted that the Croatian Competition Agency (hereafter 'CCA') is a Croatian general regulation that applies to all forms of prevention, restriction, or distortion of competition by undertakings on the territory of the Republic of Croatia or outside its territory if it affects it. ${ }^{4}$ According to the CA, the cartel, abuse of dominant position, and market concentration are three forms of conduct by market entrepreneurs that can be injurious to competition. The concentration is subject to the control of the CCA in such a way that control is carried out before the proposed concentration and it is possible only with the approval of the CCA. The concentration will be approved only if it does not distort the competition. Therefore, the CCA, headed by the Competition Council, is the competent national authority that investigates and decides on infringements of the national and EU competition law. ${ }^{5}$

One of the key powers of the CCA is the imposition of fines, which were introduced into the CA in $2009^{6}$. A fine is a specific type of legal sanction provided for by the CA and in substantive terms, this type of infringement is not considered an offense or criminal offense. ${ }^{7}$ Apart from fines, the paper deals with newly established sanctions for non-compliance with the provisions of the CA - daily fines. Daily fines are the new sanction which the CCA will issue when it considers that it is proportionate to the gravity and duration of the infringement, the consequences

Moens, G.; Trone, J., Commercial Law of the European Union, Dordrech, Springer, New York, 2010, p. 217

3 Akšamović, D., Podnošenje pritužbi Europskoj komisiji radi povrede pravila tržišnog natjecanja, Novelties in Competition Law after the Accession of the Republic of Croatia to the European Union, Ekonomski fakultet Zagreb, Zagreb, 2014, p. 144

4 Art. 2 of The Competition Act, Official Gazette No. 79/09, 80/13, 41/21

5 Bolanča Kekez, Đ., Liability for damages for infringements of the competition law provisions, Zagreb, 2019, doctoral thesis, pp. 304, 307

6 The Croatian Competition Act, Official Gazette No. 79/2009

7 Akšamović, D.; Vlaović, J., Fines in Croatian and European competition law, Journal of law and social sciences of the Law Faculty of University J. J. Strossmayer in Osijek, Vol. 33, Issue 2., 2017, p. 49 
of that infringement for other undertakings on the market and consumers, that is to say, as regards the short duration of the infringement. ${ }^{8}$ Therefore, fines and daily fines are considered as violations sui generis ${ }^{9}$ or it can be concluded that they are the sanctions for the infringements under the CA and Article 101 or 102 of the Treaty on the Functioning of the European Union ${ }^{10}$ (hereinafter called the: „TFEU“).

Finally, for this work, research of decisions taken by the CCA from 2013 to the end of 2020, imposing a fine on undertakings for non-compliance with the provisions of the CA, was carried out. The research gives the phases of observation, analysis, classification of facts, and a conclusion. It is desired to determine whether the CCA is consistent in imposing the amount of the fine concerning the mitigating and aggravating circumstances to which it refers and to conclude what are the most common mitigating and aggravating circumstances that the CCA takes into account when imposing a fine in practice.

\section{AMENDED ARTICLES OF THE TITLE VIII OF THE COMPETITION ACT}

The CA is a general regulation governing the issue of competition law in Croatia. The Act on the Amendments to Competition Act, Official Gazette No. 37/2021 ${ }^{11}$, (hereinafter called the 'AACA') was adopted to comply with the Directive (EU) 2019/1 of the European Parliament and of the Council of 11 December 2018 to empower the competition authorities of the Member States to be more effective enforcers and to ensure the proper functioning of the internal market (hereinafter called the „Directive (EU) 2019/1“).

In the continuation of the paper, only the articles of the CA from Title VIII that have been changed are presented, and the implemented changes are explained in more detail. This serves to give a simple overview of the news of that part of the amended CA and thus make it easier to understand that news.

\footnotetext{
8 Art. 63.a of the Act on the AmendAments to Competition Act, Official Gazette No. 41/2021

9 Derenčinović, D., Upravno-kaznene mjere zbog zlouporabe tržišta, Informator, No. 6316-6317, 2014, pp. 1

10 See: Article 101 and 102 of the Consolidated versions of the Treaty on European Union and the Treaty on the Functioning of the European Union (TFEU) [2016] OJ C326, 26/10/2012 P. 0001-0390

11 The Act on the Amendments to Competition Act, Official Gazette No. 37/2021
} 


\subsection{Article 60 of the Competition Act - Imposition of fines}

The word 'fine' (cro. upravno-kaznene mjere) in the CA has been amended to a different word in the AACA (cro. novčane kazne). ${ }^{12}$

Therefore, the CA has taken over the name 'fine' used in European acts, but also other national actimations, for example, in the Spanish legislation 'fine' is also used as a term for the penalty for infringement of competition law. ${ }^{13}$ Serbian Competition Act also uses the term 'fine', but for them, Commission is not authorised to impose fines in case of non-compliance with a commitent made. ${ }^{14}$

\subsection{Article 61 of the Competition Act - Fines for severe infringements of competition rules}

Article 61, regulating the fines for severe infringements of competition rules, was partly amended. As a result of the partial harmonisation of the provisions of the Act with Article 13 of the Directive (EU) 2019/1 ${ }^{15}$, stipulates that a fine up to a maximum of $10 \%$ of the value of the total turnover generated by the undertaking at the global level in the last year for which there are concluded annual financial reports, undertaking intending or negligently: either concludes a prohibited agreement or otherwise participates in an agreement which distorts competition (described in the provision of Article 8 of CA and Article 101 of TFEU), abuses a dominant position (as described by the provision of Article 13 of the CA and Article 102 of the TFEU), participates in the implementation of the prohibited concentration of an undertaking, does not act upon a decision by the CCA setting out the measures to establish competition or impose interim measures. Likewise, this Article defines the meaning of the concepts of intentions and negligence, which indicate the interpretation of the Court of Justice of the EU and not the Croatian criminal law. ${ }^{16}$

Article 61 of the CA is consistent with Article 13 of the Directive (EU) 2019/1 which states that the Member States may at least ensure that national administrative competition authorities may, by decision of their enforcement procedure,

12 Art. 46 of the Act on the Amendments to Competition Act, Official Gazette No. 41/2021

13 Figueroa, Pablo, Fines and Antitrust Infringements under the New Spanish 2007 Competition Act, Competition Law International, Vol. 5, Issue 1., 2009., pp. 39

14 Petronijevic, Srdana; Soljaga, Zoran, Commitent Procedure under Serbian Competition Act, Yearbook of Antitrust and Regulatory Studies, Vol. 16, pp. 167

15 Art. 13 of the Directive (EU) 2019/1 of the European Parliament and of the Council of 11 December 2018 to empower the competition authorities of the Member States to be more effective enforcers and to ensure the proper functioning of the internal market

16 Art. 46 of The Act on the Amendments to Competition Act, Official Gazette No. 41/2021 
impose effective, proportionate, and dissuasive fines, or may, in the course of criminal proceedings, request that such fines be imposed on them. Such fines shall be fixed in proportion to their total global income, if either intentionally or negligently: refuse to submit to the search (as referred to in Article 6); damage to stamps placed by officials or other persons accompanying them authorised or appointed by national competition authorities; in response to the question referred to in Article 6 give an incorrect or misleading answer or refuse to provide a full response; supply incorrect, incomplete or misleading information in response to the request referred to in Article 8 or provide no information within the time limit set; do not respond to the call for an interview as referred to in Article 9; do not comply with the decision referred to in Articles 10, 11 and 12 of the Directive (EU) $2019 / 1 .^{17}$

\subsection{Article 63a of the Competition Act - Daily fines}

Article 63a introduced an institute of a 'daily fine' due to full adaptation with Article 16 of the Directive (EU) 2019/1, which calls such penalties "Periodic penalty payments". Periodic penalty payments are tailored to force undertakings and associations to comply with a Commission decision. ${ }^{18}$ According to the AACA, the CCA is authorized to impose a daily fine on the entrepreneur and the association of entrepreneurs if: does not act on the CCA's request (Article 41(1) and (3) of the CA), does not respond to a mandatory interview (Article 41a of the CA), interferes with the execution of the order of the High Administrative Court of the Republic of Croatia on the conduct of an unannounced search (Article 42(6) and (7), Article 43 and Article 44 of the CA), does not act on the CCA's decision in the part of the enforcement order for infringing Article 8. or Article 13 of this Act and/or Articles 101 or 102 of the TFEU or which lay down measures relating to the undertaking's commitments referred to in Article 49 of this Act or which lay down provisional measures referred to in Article 51 of this Act (Article 58(1), 4, 10 and 11 of the CA). The same Article also regulates how such daily fines are imposed. The CCA shall issue a solution defining the total turnover of the undertaking at the global level in the preceding business year by the number of days in the financial year and multiplying the amount thus obtained by 1 day by the number of days, calculated from the date of the infringement found in the order imposing the daily penalty payment imposed by the CCA on the CCA's order imposing a

17 Art. 13 of the Directive (EU) 2019/1 of the European Parliament and of the Council of 11 December 2018

18 Lister, Charles, Dawn Raids and Other Nightmare: The European Commission's Investigatory Powers in Competition Law Matters, Journal of Reprints for Antitrust Law and Economics, Vol. 22, Issues 1 and 2, 1993 , pp. 530 
daily penalty payment. Furthermore, the maximum daily fine which may be omitted shall not exceed $5 \%$ of the value of the average daily income in the preceding business year for each day of not acting on the CCA's solution calculated from the date specified in the order. Undertakings fulfilling a liability whose non-execution was the basis for the payment of the daily penalty payment, the CCA may determine the final amount of the daily fine payment which may be lower than the amount initially established in the CCA's order. The CCA will issue a daily fine payment when it considers that the daily fine is proportionate to the gravity and duration of the infringement, the consequences of that infringement for other undertakings on the market and consumers, that is to say, as regards the short duration of the infringement and therefore the imposition of daily fine payment is appropriate and has a gross effect and all of that instead of imposing fines. ${ }^{19}$

If world regulation is looked at, it can be observed that European countries are greatly aware of the institute of daily fines or day fines in several jurisdictions, unlike, for example, an American law that has only gradually introduced such a sanction in its legal system. ${ }^{20}$

\subsection{Article 64 of the Competition Act - Method of setting fines}

Paragraph 1 of Article 64 has not been amended, on the other hand, a completely new paragraph has been introduced. It states that if the infringement committed by the association of undertakings relates to the activities of its members, the maximum amount of the fine that can be imposed on the association of undertakings cannot, in any case, exceed $10 \%$ of the sum of the total revenue generated worldwide by each member of the association who acted on the market where the infringement occurred by the association of undertakings. When imposing a fine on an association of undertakings for violation of this Act and Articles 101 or 102 of the TFEU, the CCA will take into account the income of its members or may take into account the income of the association of undertakings. If the CCA finds that the association of undertakings is not solvent and cannot pay the fine referred to in paragraph 2 of this Article, the association of undertakings shall request payments and/or additional payments from its members in order to settle the fine. The financial obligation of each member of the association referred to in paragraph 4 of this Article relating to the payment of a fine for that infringement may not exceed $10 \%$ of its total worldwide revenue in the year for which there are closed financial statements. If the fine imposed referred to in paragraph 2 of this Article is not fully paid within the time limit set by the CCA, the CCA shall

\footnotetext{
19 Art. 63.a of the Act on the AmendAments to Competition Act, Official Gazette No. 41/2021

20 Hillsman, Sally T., Fines and Day Fines, Crime and Justice: A Review of Research, Vol. 12, pp. 49
} 
request the payment of the fine or its balance directly from any undertaking whose representatives were members of the decision-making bodies of that association of undertakings. If the fine imposed referred to in paragraph 2 of this Article cannot be charged in the manner referred to in paragraph 6 of this Article, the CCA shall request the payment of the fine or its remaining amount from each member of the association of undertakings acting on the market where the infringement occurred. The obligation referred to in paragraphs 4 to 7 of the same article does not apply to an undertaking which demonstrates that it has not implemented a decision of the association of undertakings representing an infringement and who did not know that such a decision existed or had actively fenced itself off from such a decision before the start of the procedure. The Payers of the fine referred to in paragraphs 6 and 7 of that Article will be determined by the CCA in a decision imposing a fine. ${ }^{21}$

\subsection{Article 65 and 65a of the Competition Act - Reduction of / immunity from fines}

Article 65 has changed completely and it is now in line with articles 17 to 22 of the TFEU which are part of Chapter VI governing leniency programs for secret cartels. New Article 65 states that the CCA may exempt from the payment of a fine from that participant of a cartel or a secret cartel that first informs the CCA of a cartel or a secret cartel and provides it with information, facts, and evidence enabling the CCA to initiate proceedings and carry out a targeted unannounced search relating to a secret cartel, provided that the CCA does not yet have sufficient evidence to initiate the proceedings and conduct a targeted unannounced search or has not yet carried out such a search or which, according to the CCA, are sufficient to be able to identify the infringement covered by the penitentiary programme referred to in Article 8(1) of the Regulation. of this Act and/or Article 101 of the TFEU, provided that the CCA does not yet have sufficient evidence to establish that infringement and that no other undertaking has previously met the conditions for authorisation of leniration in relation to that secret cartel. An undertaking may submit such an application as a full or summed-up application for leniration. The exemption from payment of a fine cannot apply to an undertaking that has forced other undertakings to join or remain in a cartel. The CCA may impose a reduced fine on those participants in a cartel or a secret cartel that does not qualify for leniency but have provided the CCA with additional valid evidence that constitutes significant added value for demonstrating an infringement covered by the leniency programme, in relation to the evidence already available to

21 Art. 64(2-9) of the Act on the Amendments to Competition Act, Official Gazette No. 41/2021 
the CCA at the time of filing the application. The CCA shall not take into account such additional facts as a result of an increase in fines compared to the fines that would otherwise be imposed on participants in a cartel or secret cartel. Applicants for leniency from fines or for the reduction of the fine-penance, statements of penitentiaries concerning full or abbreviated applications are submitted in Croatian or in another official language of the European Union agreed bilaterally between the CCA and the applicant. Imposing a fine under this Act is of no effect on the criminal liability of the person to whom that fine was imposed. On the proposal of the CCA, the Government of the Republic of Croatia will elaborate in detail the criteria for exemption from the fine or for the reduction of the fine, in accordance with the criteria arising from the application of competition rules in the European Union, within the meaning of Article 74 of the CA. ${ }^{22}$

Behind Article 65 of the European adds Article 65a which states that current and former directors, managers, and other employees of undertakings that have submitted to the CCA for lenient exemption under the lenient scheme will not be fined in administrative proceedings and administrative disputes, in connection with their participation in a cartel or secret cartel to which the application for lenient from the fine applies if: 1 . application for leniency of the entrepreneur meets the criteria set out in the regulation governing the criteria for leniency or reduced fines 2 . current and former directors, managers and other employees actively cooperate with the CCA and 3. application for exemption from the fine of entrepreneurs is submitted before these current and former directors, managers and other employees learned from the competent authorities of the procedure leading to the imposition of fines referred to in paragraph 1 of this Article. If the protection referred to in paragraph 1 of this Article is not the competent CCA but a competition authority in another Member State of the European Union, the CCA shall provide the necessary contacts between that authority of another Member State and the body responsible for sanctioning or prosecuting when the competent authorities of the Republic of Croatia are responsible for sanctioning or prosecuting them. The decision on the initiation of criminal proceedings against persons referred to in paragraph 1 of this Article is made by the State Attorney, in accordance with the regulations of the criminal legislation of the Republic of Croatia. For the reasons of paragraph 3 of this Article, the Public Prosecutor may decide not to initiate criminal proceedings or may propose to the competent court an easing of the sanction to be imposed in criminal proceedings, if the Public Prosecutor considers that the contribution of the person referred to in paragraph 1 of this Article in the detection of cartels exceeds the interest of prosecuting and/or sanctioning those persons. This Article is without prejudice to the right of injured parties who

22 Art. 65 of the Act on the Amendments to Competition Act, Official Gazette No. 41/2021 
have suffered damage caused by an infringement of competition law to claim full compensation for that damage, following the regulation governing infringement compensation procedures. ${ }^{23}$

\section{MITIGATING AND AGGRAVATING CIRCUMSTANCES FOR THE IMPOSITION OF FINES IN LAW AND PRACTICE}

The continuation of the work will analyse the legal provisions governing the mitigating and aggravating circumstances that the CCA takes into account as it imposes fines on undertakings. After that, the results of the research of mitigating and aggravating circumstances in CCA's practice that have been carried out to draw up the conclusions of this work are presented.

\subsection{Mitigating and aggravating circumstances for imposing a fine through legal provisions}

Article 64 has not changed and it regulates mitigating and aggravating circumstances taken into account when imposing a fine or a daily fine. This takes into account all mitigating and aggravating circumstances such as the gravity of the infringement, the duration of the infringement, and the consequences and infringements for other market undertakings and consumers. The two-stage methodology for calculating the fine shall apply by establishing the basic amount of the penalty for the undertaking and then reducing or increasing the amount thus determined depending on the mitigating and/or aggravating circumstances identified. The basic amount of the fine shall be calculated up to a maximum of $30 \%$ of the income generated by the undertaking solely from the performance of activities in the established relevant market in which this Act or Article 101 or 102 of the TFEU has been infringed, which is multiplied by the number of years of the infringement and thereafter decreases or increases depending on the mitigating and/or aggravating circumstances identified. ${ }^{24}$

Mitigating circumstances under the Act will be considered: the delivery of evidence of the termination of unlawful conduct, promptly upon the knowledge of the entrepreneur about the initiation of proceedings by the CCA. Exceptionally, in the case of cartels, the delivery of evidence of an interruption of unlawful conduct will not be regarded as a mitigating circumstance. Then the provision of evidence of infringement of this Act or Article 101 or 102 of the TFEU as a result of the inaudance of the undertaking and the provision of evidence that the

\footnotetext{
23 Art. 65a of the Act on the Amendments to Competition Act, Official Gazette No. 41/2021

24 Art. 64(2-3) of the Croatian Competition Act, Official Gazette No. 79/2009, 80/2013, 41/2021
} 
undertaking, although a participant in the prohibited agreement did not apply that agreement, or that in the relevant market, despite the existence of the agreement, acted per competition regulations. The most mitigating circumstance is the cooperation of entrepreneurs with the CCA in a manner and to the extent that exceeds the obligations of the entrepreneur for the release or reduction of the fine regulated by the Act. ${ }^{25}$

On the other hand, aggravating circumstances are particularly: the continuation of the unlawful conduct of the undertaking or the repetition of the same or similar conduct in breach of the provisions of this Act or Article 101 or 102 TFEU, following the service of the CCA's decision establishing that such conduct infringed competition by the undertaking. In this case, the basic amount of the fines shall be increased by $100 \%$ for each identified case of repeated infringement, refusal to cooperate with the CCA or obstruction of the CCA during the implementation of the procedure, the role of the initiator or instigator of other undertakings to the infringement of this Act and Article 101 or 102 of the TFEU, i.e. any actions taken by that undertaking in order to ensure the participation of other undertakings in the infringement. ${ }^{26}$

According to Article 64, CCA may increase fines if necessary for confiscation of the proceeds generated by the undertaking in breach of the Act or Article 101 or 102 of the TFEU, where such benefit can be assessed. However, the CCA may also further reduce the amount of the fine to an undertaking in a serious financial situation if it demonstrates that imposing such a penalty would irreversibly jeopardize its economic viability and lead to a complete loss of the value of its assets. Likewise, the CCA is entitled to impose symbolic fines if the infringement of competition was not significant, i.e. there was no negative impact on the market. Article 64 The last paragraph of the 17th Act was also entered, which states that the Government of the Republic of Croatia will elaborate in detail the criteria for imposing the fine referred to in this Article in accordance with the criteria arising from the application of competition rules in the European Union by decree of the CCA. ${ }^{27}$

\subsection{Research of mitigating and aggravating circumstances that the CCA took into account when imposing fines from 2013 to the end of 2020}

For the purpose of this work, research of decisions taken by the CCA from 2013 to the end of 2020, imposing a fine on undertakings for non-compliance with

Art. 64(4) of the Croatian Competition Act, Official Gazette No. 79/2009, 80/2013, 41/2021

Art. 64(5) of the Croatian Competition Act, Official Gazette No. 79/2009, 80/2013, 41/2021

Art. 64(7-9) of the Croatian Competition Act, Official Gazette No. 79/2009, 80/2013, 41/2021 
the provisions of the CA, was carried out. The research is based on the inductive method, therefore, after the phases of observation, analysis and classification of facts, a conclusion is made.

This research aims to determine whether the CCA is consistent in imposing the amount of the fine in relation to the mitigating and aggravating circumstances to which it refers, that is to say, it is desired to determine whether there is a connection between the amount of the fine and the number of mitigating and aggravating circumstances for imposing it. The survey also wants to see what are the most common mitigating and aggravating circumstances that the CCA took into account when imposing a fine and also whether there are large discrepancies between the highest and lowest fines imposed.

In the continuation of the paper, there is a tabular presentation of the mitigating and aggravating circumstances that the CCA took into account when imposing fines. The table gives the date of the decision and the classification of the case, the name of the case, the amount of the fine, and the mitigating and aggravating circumstances to which the CCA referred for the imposition 


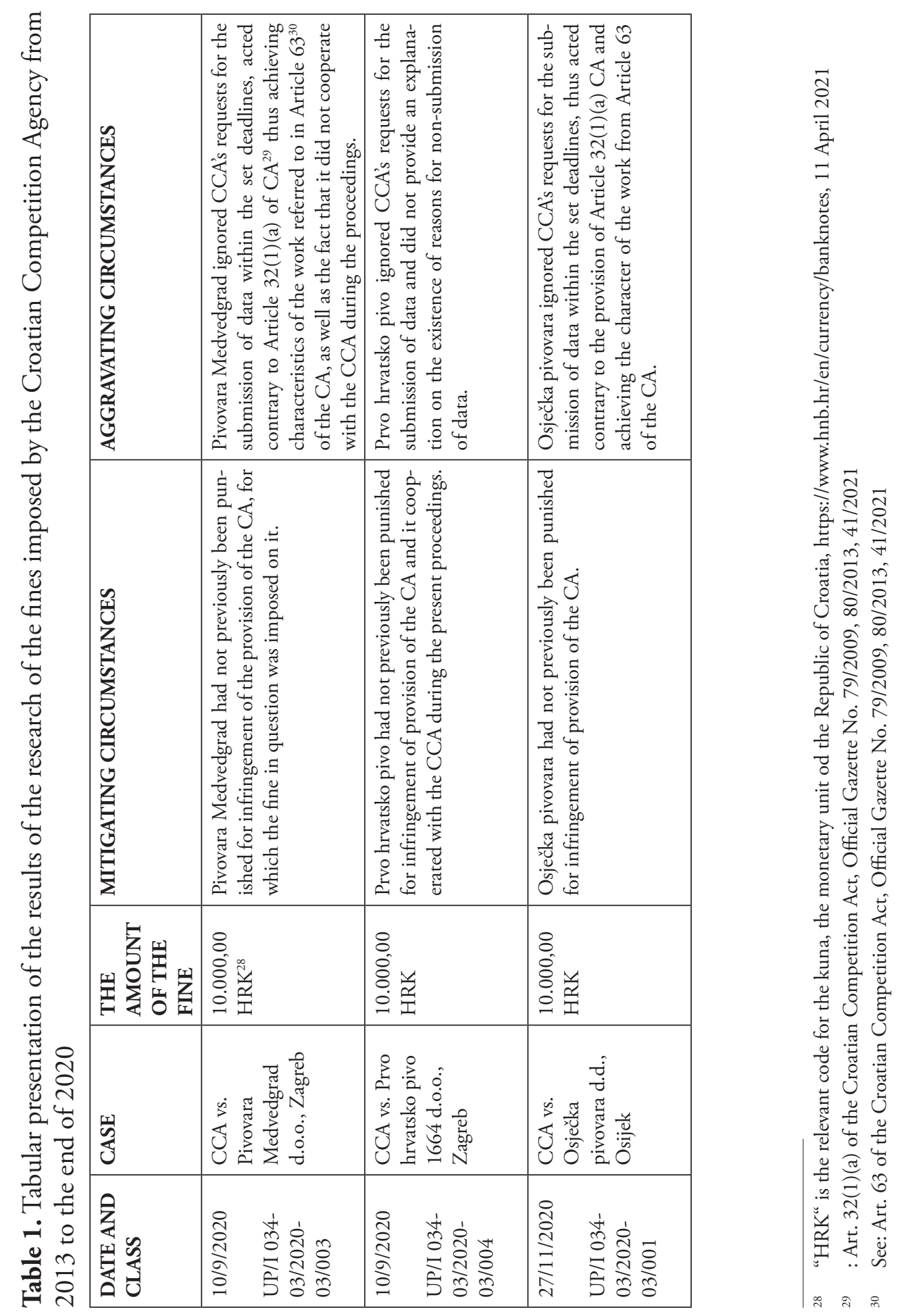




\begin{tabular}{|c|c|c|c|}
\hline 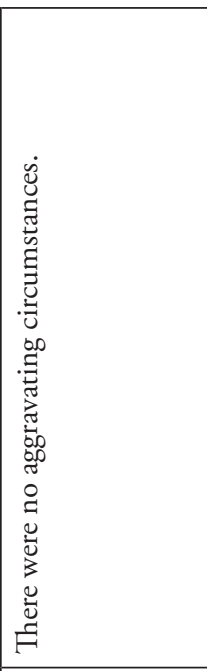 & 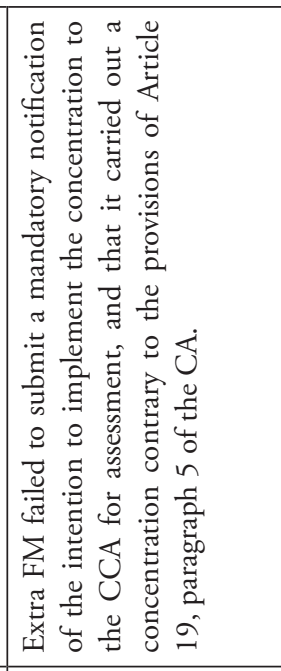 & 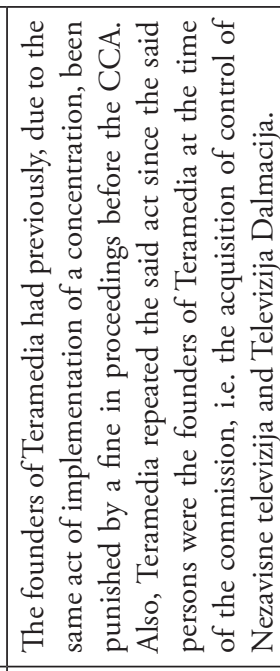 & 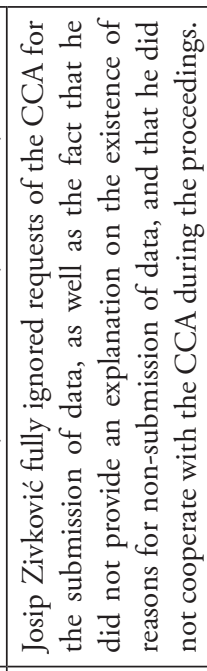 \\
\hline 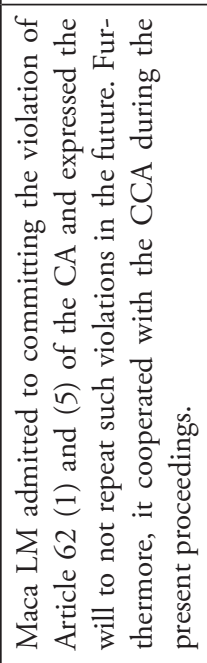 & 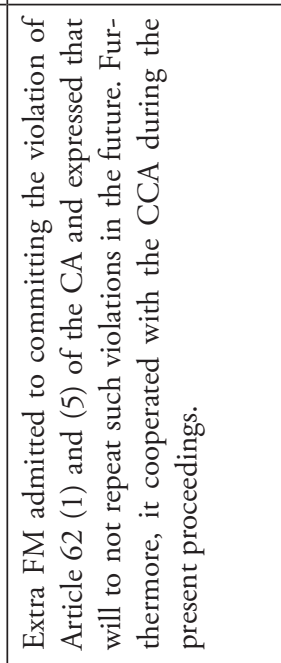 & 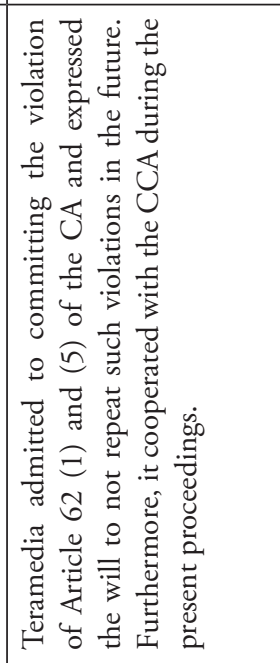 & 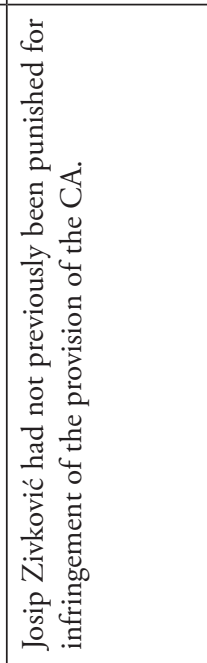 \\
\hline 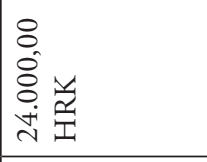 & 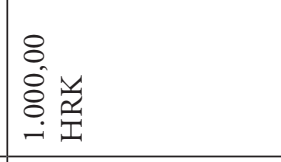 & 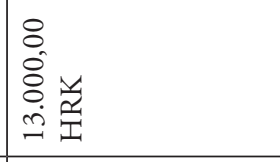 & 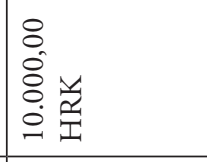 \\
\hline 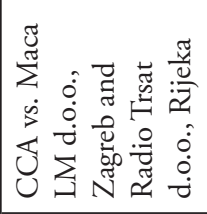 & 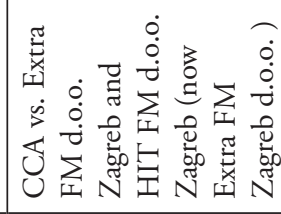 & 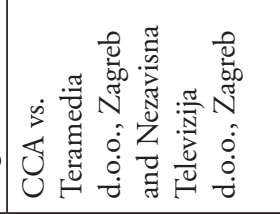 & 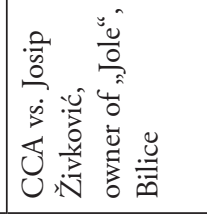 \\
\hline 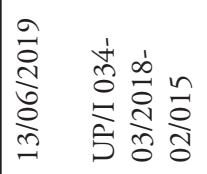 & 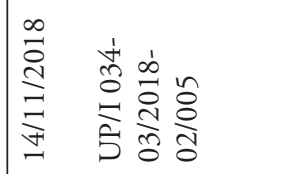 & 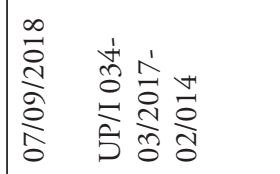 & 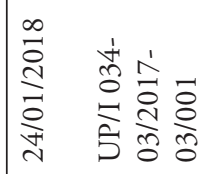 \\
\hline
\end{tabular}




\begin{tabular}{|c|c|c|c|c|}
\hline 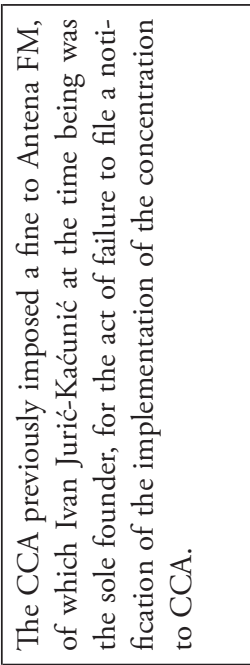 & 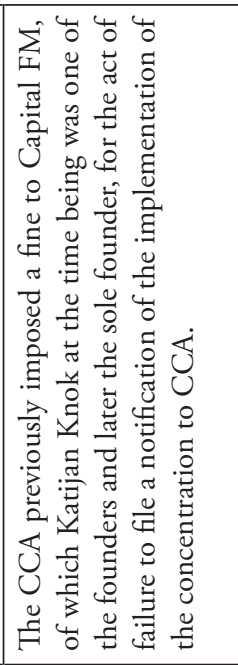 & 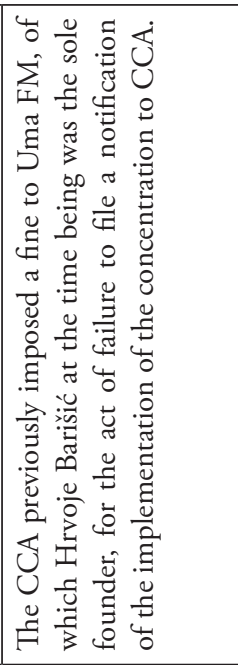 & 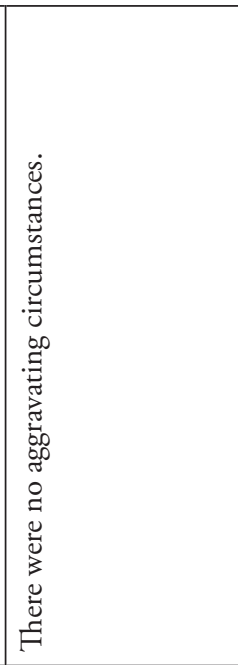 & 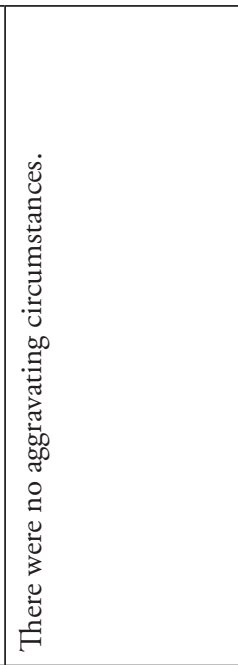 \\
\hline 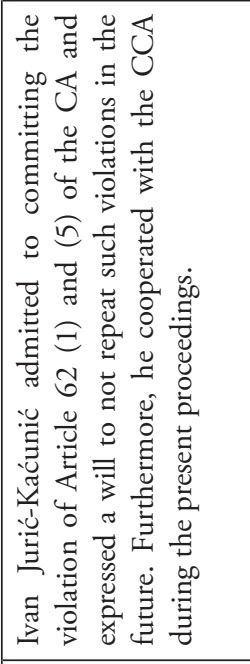 & 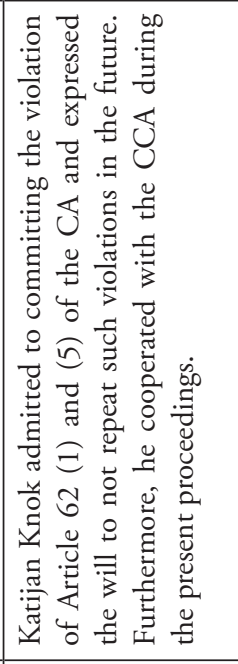 & 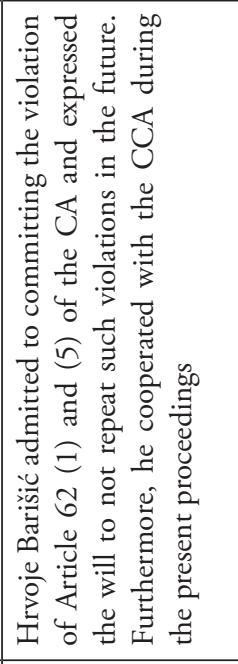 & 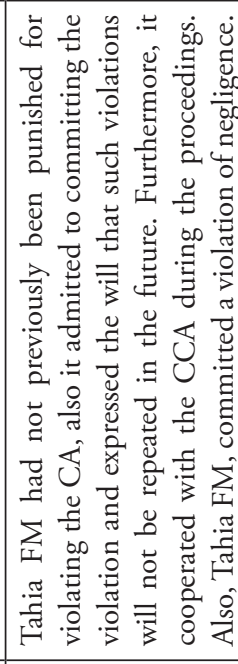 & 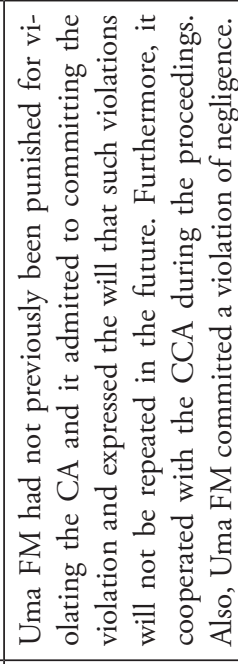 \\
\hline 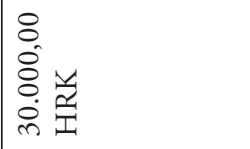 & 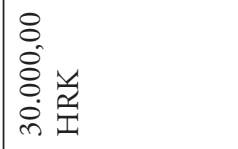 & 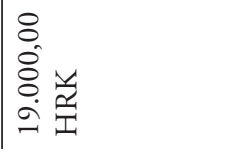 & 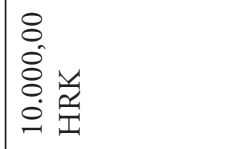 & 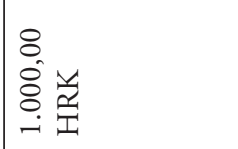 \\
\hline 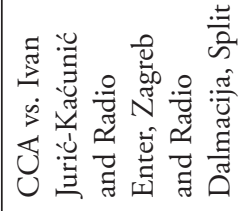 & 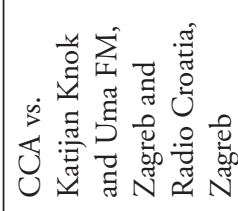 & 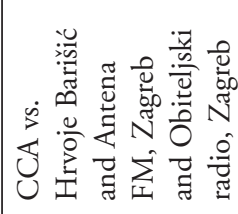 & 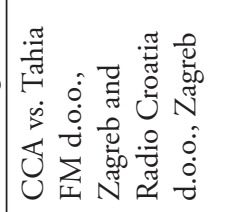 & 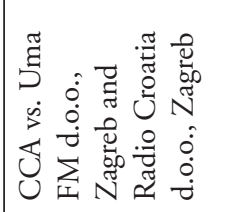 \\
\hline 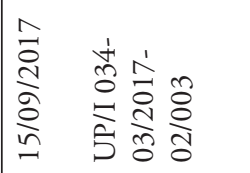 & 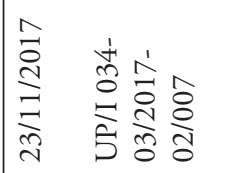 & 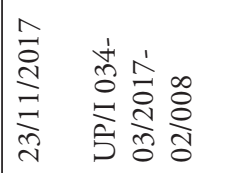 & 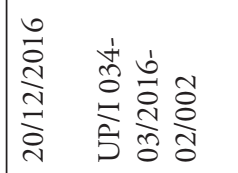 & 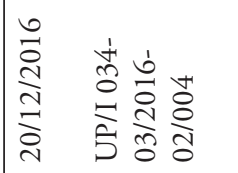 \\
\hline
\end{tabular}




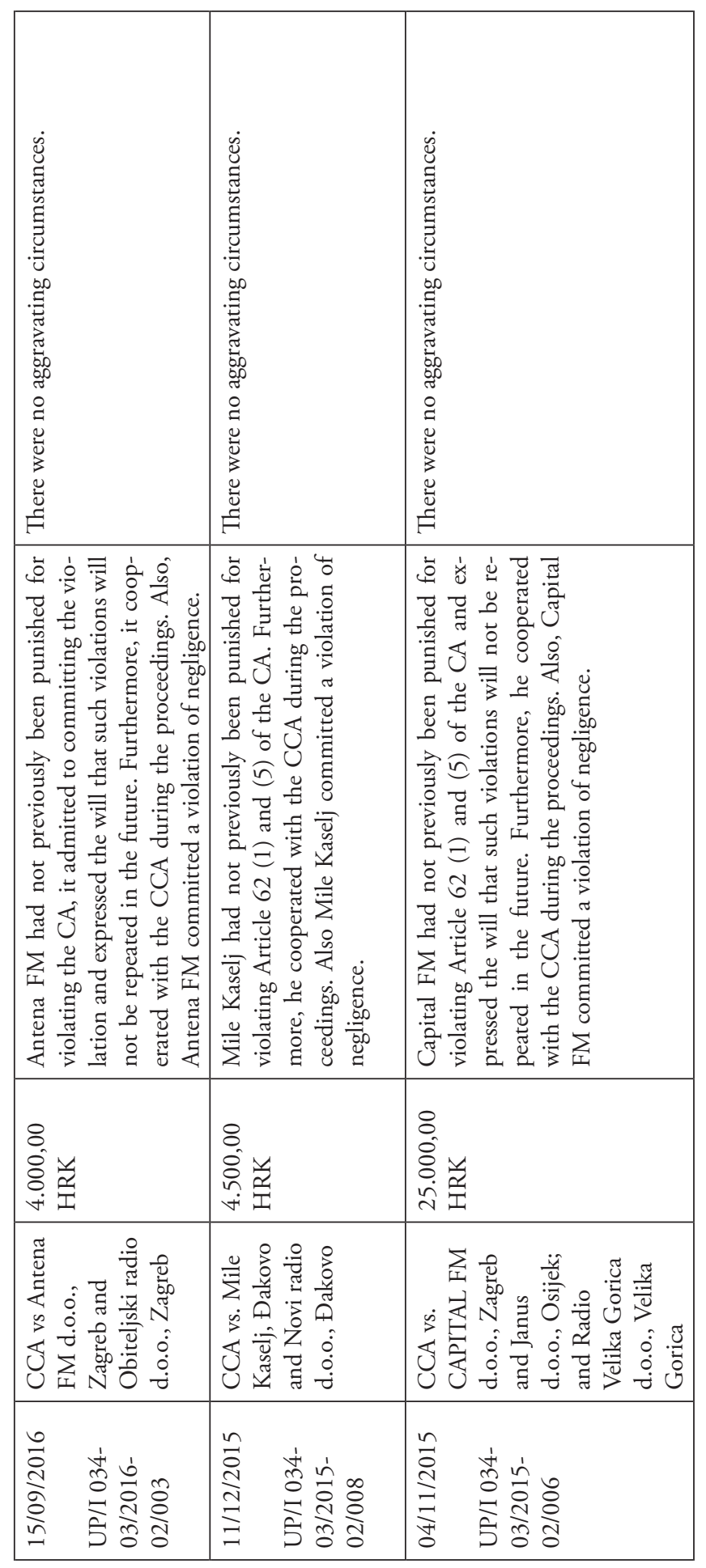




\begin{tabular}{|c|c|c|}
\hline 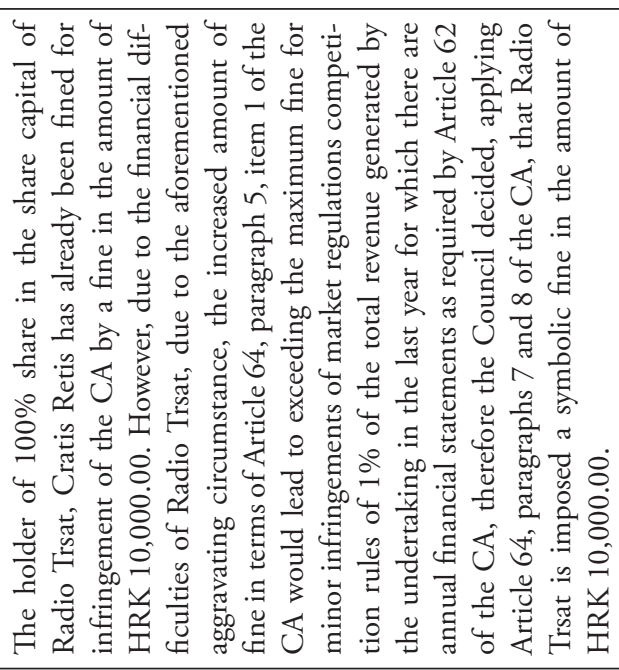 & 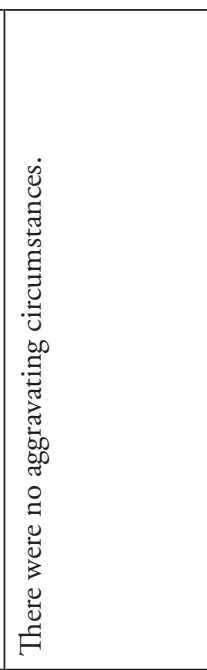 & 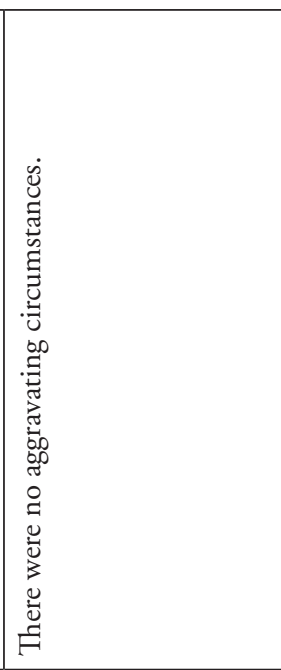 \\
\hline 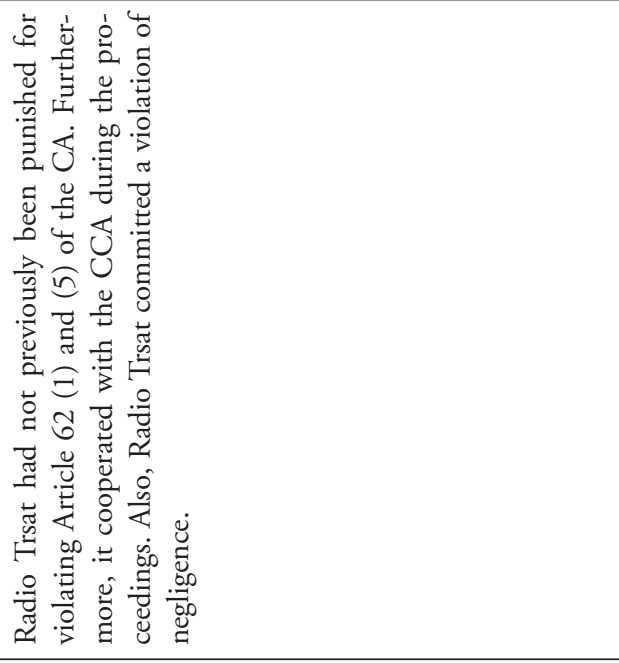 & 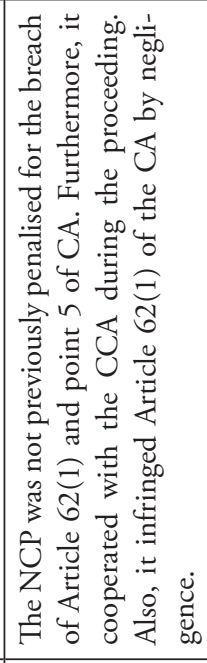 & 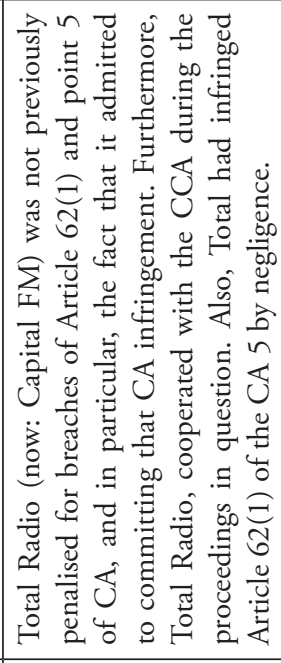 \\
\hline 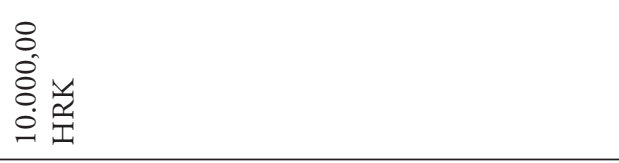 & 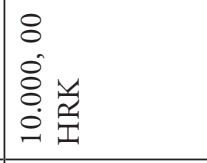 & $\begin{array}{l}8 \\
8 \\
0 \\
8 \\
0 \\
0 \\
0 \\
1\end{array}$ \\
\hline 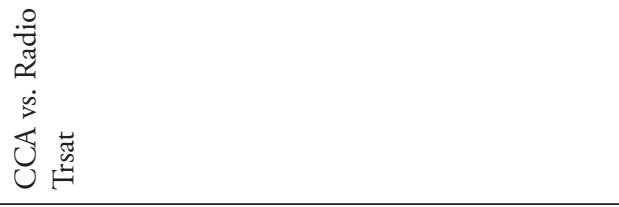 & 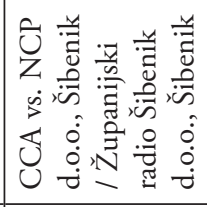 & 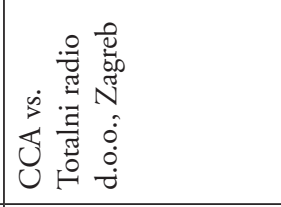 \\
\hline 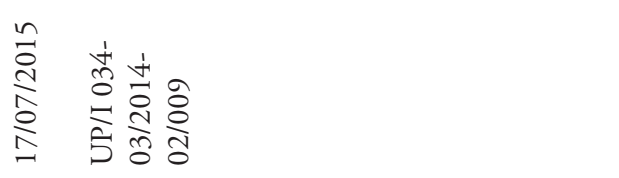 & 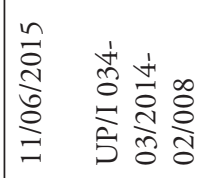 & 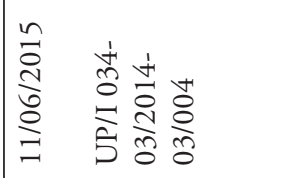 \\
\hline
\end{tabular}




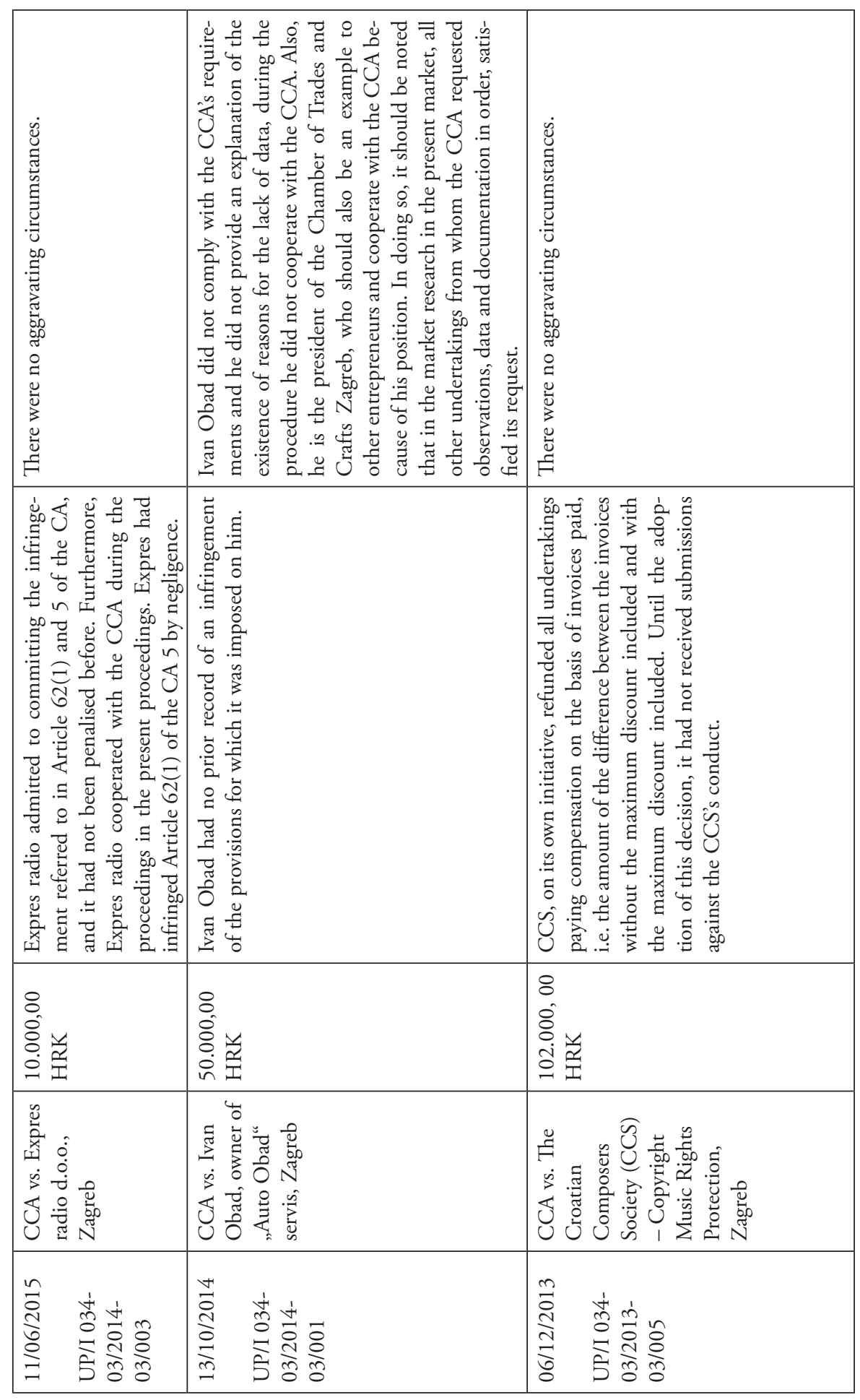

Tena Konjević: FINES AND DAILY FINES UNDER THE ACT ON THE AMENDMENTS TO... 


\begin{tabular}{|c|c|}
\hline 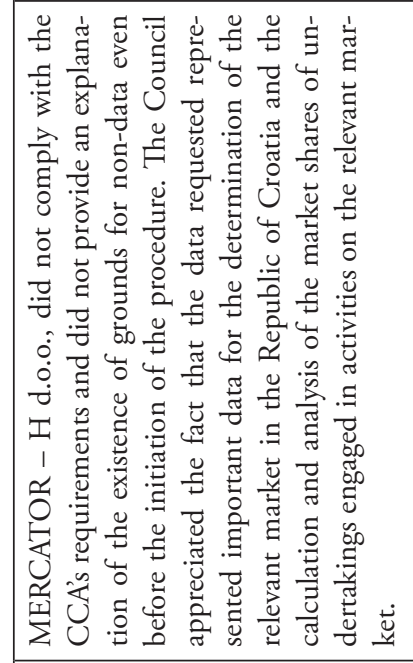 & 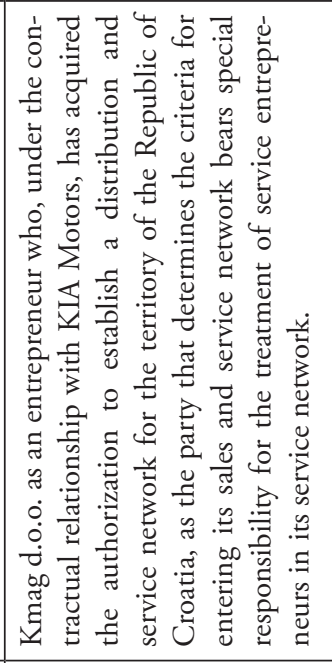 \\
\hline 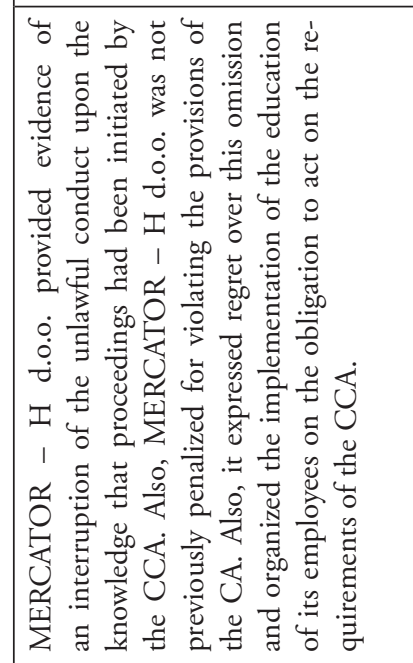 & 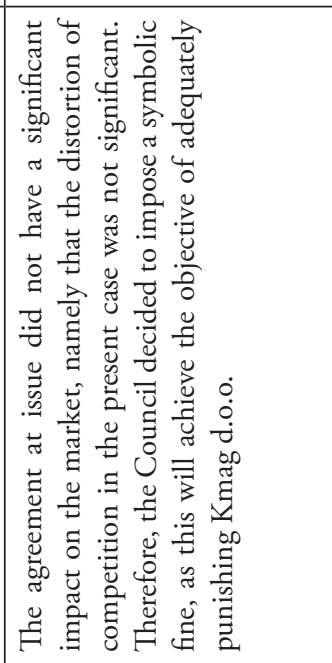 \\
\hline 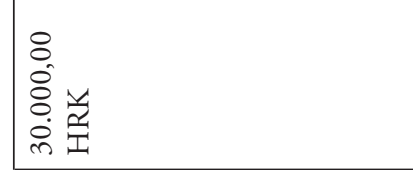 & 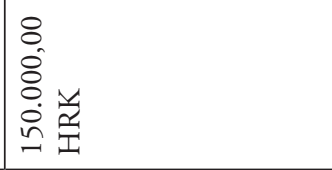 \\
\hline 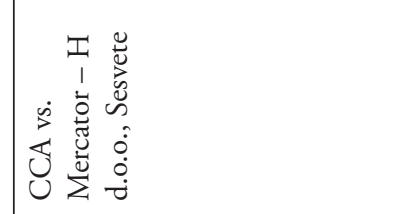 & 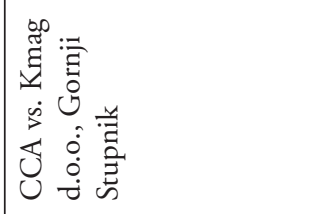 \\
\hline 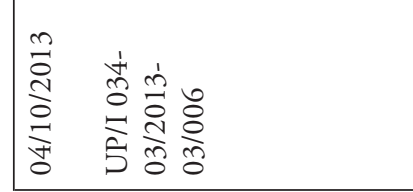 & 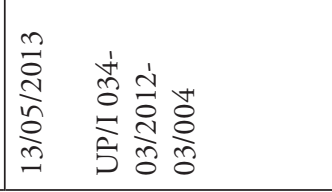 \\
\hline
\end{tabular}


After observing the table, it is necessary to make an analysis of the obtained research results.

Firstly, it is important to present the reasons for imposing fines shown in the table. Therefore, reasons for imposing fines in those cases were: failure to submit the requested statements and data with the deadline (set by the second CCA request), failure to submit within the deadline for mandatory notification of intent implementation of concentrations on the assessment of the CCA, carrying out the concentration and gaining direct or indirect control over the other undertaking and not acting upon the received request. Also, there is specific reasons for imposing a fine in the case „CCA vs. The Croatian Composers Society (CCS) - Copyright Music Rights Protection “31. Therefore, Croatian Composers' Society - Copyright Music Rights Protection, is fined for abusing his dominant position in collecting fees for reproducing a work of authorial property for private or other own use in the Republic of Croatia, in such a way that in the period from 1 January 2013 to 31 December 2013, he was sentenced to 10 years in prison. From 1 January 2006 until the date of adoption of the CCA's decision, i.e. 3 November 2009, it applied to entrepreneurs for similar activities different discounts on fees, thus applying an uneven playing field to the same certain undertakings have disadvantaged the market for the sale of products for which compensation is paid in relation to their competition and thereby distorted competition in that market within the meaning of Article 16(2) of paragraph 3 of the CA. Also, there is one more specific reason for imposing a fine in the case „CCA vs. Kmag d.o.o.“. Kmag d.o.o. was imposed a symbolic fine for restricting competition with its authorised service persons in the relevant market for the sale of spare parts and the provision of KIA motor vehicle repair and maintenance services on the territory of the Republic of Croatia between 1 January 2006 and 2 December 2010, within the meaning of Article 9(1) of the CA.

In the continuation of the work, the mitigating and aggravating circumstances referred to by the CCA in the cases shown in the table will be presented.

The mitigating circumstances invoked by the CCA in the cases shown in the table are: no prior punishment for non-compliance with the law, cooperation with the CCA during the proceeding, recognition of the violation, expressing that it will no longer commit such violations, committing an infringement of the CA of negligence and termination of unlawful conduct following the fact that the CCA has

31 Croatian Competition Agency against The Croatian Composers Society - Copyright Music Rights Protection, HDS-ZAMP, Zagreb, No. UP/I 034-03/2013-03/005 
initiated proceedings. ${ }^{32}$ But, in addition to the above mitigating circumstances mentioned in the vast majority of cases, it is necessary to mention separate specific cases which are in the table. In the case „CCA vs. The Croatian Composers Society (CCS) - Copyright Music Rights Protection" ${ }^{\text {"33 }}$ the CCA took the following fact as a mitigating circumstance: CCS, on its own initiative, refunded all undertakings paying compensation on the basis of invoices paid, i.e. the amount of the difference between the invoices without the maximum discount included and with the maximum discount included. Furthermore, the specificity of „CCA vs. Mercator $-\mathrm{H}$ d.o.o. ${ }^{\text {" }}{ }^{34}$ the case is that CCA took into account as a mitigating circumstance the fact that this entrepreneur organized training for his employees to avoid further violation of the CA. Also, in the case „CCA vs. Kmag d.o.o." 35 the mitigating circumstance was the fact that the agreement at issue did not have a significant impact on the market, namely that the distortion of competition in the present case was not significant.

The aggravating circumstances invoked by the CCA in the cases shown in the table are: ignoring requests to submit data by a certain deadline or the failure to file a notification of the implementation of the concentration to CCA, failure to explain the existence of reasons for non-submission of dana, non-cooperation with the CCA during the procedure, the implementation of a concentration contrary to Article 19. of the CA and the existence of a prior penalty for non-compliance with the CA. However, as with mitigating circumstances, there are certain specific aggravating circumstances that the CCA referred to in the presented cases. In the case „CCA vs. Teramedia d.o.o., Zagreb and Nezavisna Televizija d.o.o." ${ }^{36}$ the aggravating circumstance was the fact that the founders of Teramedia had previously, due to the same act of implementation of a concentration, been punished by a fine in proceedings before the CCA. Also, Teramedia repeated the said act since the said persons were the founders of Teramedia at the time of the commission, i.e. the acquisition of control of Nezavisne televizija and Televizija Dalmacija. Also, the specificity of the case „CCA vs. Radio Trsat ${ }^{\text {" } 37}$ is that the holder of $100 \%$ share in the share capital of Radio Trsat, Cratis Retis has already been fined for infringement of the CA by a fine in the amount of HRK 10,000.00. However, due to the

32 The data are based on the conclusions obtained from the previously presented table and based on the research conducted for the purposes of this paper.

33 Croatian Competition Agency against The Croatian Composers Society - Copyright Music Rights Protection, HDS-ZAMP, Zagreb, No. UP/I 034-03/2013-03/005

34 Croatian Competition Agency against Mercator - H d.o.o., Sesvete, No. UP/I 034-03/2013-03/006

35 Croatian Competition Agency against Kmag d.o.o., Gornji Stupnik, No. UP/I 034-03/2012-03/004

36 Croatian Competition Agency against Teramedia d.o.o., Zagreb and Nezavisna Televizija d.o.o., Zagreb, No. UP/I 034-03/2017-02/014

37 Croatian Competition Agency against Radio Trsat, No. UP/I 034-03/2014-02/009 
financial difficulties of Radio Trsat, due to the aforementioned aggravating circumstance, the increased amount of fine in terms of Article 64, paragraph 5, item 1 of the CA would lead to exceeding the maximum fine for minor infringements of market regulations competition rules of $1 \%$ of the total revenue generated by the undertaking in the last year for which there are annual financial statements as required by Article 62 of the CA, therefore the Council decided, applying Article 64, paragraphs 7 and 8 of the CA, that Radio Trsat is imposed a symbolic fine in the amount of HRK 10,000.00. Furthermore, in the case „CCA vs. Ivan Obad, owner of „Auto Obad" servis" 38 the aggravating circumstance was the fact the Ivan Obad is the president of the Chamber of Trades and Crafts Zagreb, who should also be an example to other entrepreneurs and cooperate with the CCA because of his position. In doing so, it should be noted that in the market research in the present market, all other undertakings from whom the CCA requested observations, data and documentation in order, satisfied its request.

If the level of fines imposed by the CCA is observed, it can be seen that there is a significant difference between the highest and the minimum fine. According to the data in the table, the most common fine is 10.000,00 HRK, of which the smallest one was HRK 1,000, and the highest was HRK 150,000. There is no proportional relationship between the amount of the fine and the mitigating and aggravating circumstances. Cases, where there were more mitigating circumstances and no aggravating at all, were punished with higher fines and those with more aggravating circumstances than mitigating, were punished with lower fines.

Furthermore, it is interesting to see the relationship between mitigating and aggravating circumstances and the amount of the fine that was imposed in cases in table. For example, if you look at cases „CCA vs. Maca LM d.o.o., Zagreb and Radio Trsat d.o.o., Rijeka“ ${ }^{39}$ and „CCA vs. Extra FM d.o.o. Zagreb and HIT FM d.o.o. Zagreb (now Extra FM Zagreb d.o.o. ) "40 in the table, you can see that the difference in the amount of the fine is significant (HRK 24,000 vs. HRK $1,000.00)$. However, if you look at the mitigating circumstances in both cases, it is seen that they are identical. In contrast, in the first case, where a much higher fine of HRK 24.000,00 was imposed, there are no aggravating circumstances at all, while in the second case, where the fine is only HRK $1.000,00$, there are several significant aggravating circumstances. Both entrepreneurs committed a minor

38 Croatian Competition Agency against Ivan Obad, owner of „Auto Obad“ servis, Zagreb - repair, maintenance and resale, No. UP/I 034-03/2014-03/001

39 Croatian Competition Agency against Maca LM d.o.o., Zagreb and Radio Trsat d.o.o., Rijeka, No. UP/I 034-03/2018-02/015

40 Croatian Competition Agency against Extra FM d.o.o. Zagreb and HIT FM d.o.o. Zagreb (now Extra FM Zagreb d.o.o. ), No. UP/I 034-03/2018-02/005 
violation of the provisions of the law, so the fine may amount to a maximum of $1 \%$ of the value of the total income generated by the entrepreneur in the last year for which there are concluded annual financial statements. In the case „CCA vs. Maca LM d.o.o., Zagreb and Radio Trsat d.o.o., Rijeka" the Council decided to determine the basic amount of the fine of HRK 48,000.00 for failing to notify the intention to implement and enforce the concentration of Maca LM and Radio Trsat, and thus entrepreneurs Vanga, Maca LM and Miroslav Kraljević and Maca LM and Radio Brod, and due to mitigating circumstances, this amount was reduced, which makes a total of a single amount of HRK 24,000.00, which represents $0.71 \%$ of the total revenue generated by the entrepreneur Maca LM in 2017. On the other hand, in the case „CCA vs. Extra FM d.o.o. Zagreb and HIT FM d.o.o. Zagreb (now Extra FM Zagreb d.o.o. )" the Council decided in the present case to determine the basic amount of a fine of HRK 5 000,00 for missing notification of the intention to implement and enforce the Extra FM and Extra FM Zagreb concentration, before HIT FM, and, due to mitigating circumstances, this amount represents $0,71 \%$ of the total revenue generated by Extra FM in 2017. From these two cases, it can be seen that the final fine does not depend much on the number or existence of mitigating and aggravating circumstances as on the broader aspects of the case that the CCA takes into account.

Therefore, it can be observed that the fines are significantly different in some cases, namely that there is no continuity in the amount of the fine imposed by the CCA. It can be concluded that the fines imposed by the CCA mostly depend on whether there has been a serious or minor infringement of the CA. A fine of up to $10 \%$ of the value of the total income generated by the entrepreneur at the global level in the last year for which the annual financial statements have been concluded shall be imposed on the entrepreneur who intentionally or negligently violates regulations. ${ }^{41}$ On the other hand, a fine of up to $1 \%$ of the value of the total income generated by the entrepreneur in the last year for which annual financial reports have been concluded shall be imposed on the entrepreneur - party in the procedure that commits a minor violation of regulations. ${ }^{42}$ Also, a fine of $10,000.00$ to $100,000.00$ kuna shall be imposed on an entrepreneur who does not have the position of a party in the procedure, and who does not act upon the request of the Agency. ${ }^{43}$ It must be emphasized that the survey was conducted before the daily fines ${ }^{44}$ had never been imposed, so they will not be mentioned in the survey results. Furthermore, the maximum amount of a fine that may be

\footnotetext{
41 Art. 61 of the Croatian Competition Act, Official Gazette No. 79/2009, 80/2013, 41/2021

42 Art. 62 of the Croatian Competition Act, Official Gazette No. 79/2009, 80/2013, 41/2021

43 Art. 63 of the Croatian Competition Act, Official Gazette No. 79/2009, 80/2013, 41/2021

44 Art. 63.a of the Croatian Competition Act, Official Gazette No. 79/2009, 80/2013, 41/2021
} 
imposed on the basis of CA may in no case exceed the amount of $10 \%$ of the value of the total income generated by the entrepreneur in the last year for which annual financial reports have been concluded within the meaning of Article 61 of the CA. ${ }^{45}$ However, the CCA is not strictly limited by the amount of the fine it may impose, but may, at its discretion, adjust the fine to each undertaking depending on the existence of mitigating and aggravating circumstances for its imposition. The mitigating and aggravating circumstances that the CCA can take into account have already been mentioned above, however, some mitigating and aggravating circumstances that are not provided by CA can be seen in the table, as a result of the CCA's discretionary assessment.

\section{CONCLUSION}

The Competition Act (Official Gazette 79/09, 80/13) has been changed due to the obligation to comply with the Directive (EU) 2019/1 of the European Parliament and of the Council of 11 December 2018 to empower the competition authorities of the Member States to be more effective enforcers and to ensure the proper functioning of the internal market. The changes were significant throughout the Act, and especially in Title VIII of the CA governing penalty clauses.

The Croatian Competition Agency is a general, national regulatory authority responsible for the protection of competition in all markets and it imposes fines and daily fines. The term "fine“ or cro. upravno-kaznene mjere in the CA has been amended to a term cro. novčane kazne in the AACA. Article 61, regulating the fines for severe infringements of competition rules, was partly amended and Article 63a introduced an institute of a "daily fine" that have not existed in the CA until now. The CCA will issue a daily fine payment when it considers that the daily fine is proportionate to the gravity and duration of the infringement, the consequences of that infringement for other undertakings on the market and for consumers, that is to say, as regards the short duration of the infringement and therefore the imposition of daily fine payment is appropriate and has a gross effect and all of that instead of imposing fines. Furthermore, a new paragraph in Article 64 regulates the maximum amount of the fine that can be imposed on the association of undertakings. Finally, Article 65 has changed completely and it is now in line with articles 17 to 22 of the TFEU which are part of Chapter VI governing leniency programmes for secret cartels.

Following a tabular overview of mitigating and aggravating circumstances that the CCA considered into account when imposing a fine from 2013 and the end of

45 Art. 64 of the Croatian Competition Act, Official Gazette No. 79/2009, 80/2013, 41/2021 
2020, it can be concluded that the most common mitigating circumstances that CCA took into account when imposing fines were: previous impunity, acknowledgment of the infringement committed, cooperation with the CCA during the procedure, confirmation that the infringement will no longer be committed in the future, the existence of an agreement between the parties that is partially applied in practice, infringing, self-initiation recovery of all amounts subscribed, expression of penance for the work done. On the other hand, the table shows that the most common aggravating circumstances were: ignoring requests for data, avoiding the delivery of data to the CCA, missing the mandatory notification of the intention to implement the concentration, earlier penalty for the same act, and non-cooperation with the CCA. It can be concluded that there is no continuity in the amount of the fine imposed by the CCA, nor is there a certain consistent relationship between the number of mitigating and aggravating circumstances and the amount of the fine. Also, it should be inferred that the biggest role in imposing a fine, according to the data in the table, is the fact that the infringement belongs to a serious or minor infringement of the CA and in broader circumstances that the CCA takes into account at its discretion.

\section{REFERENCES}

\section{BOOKS AND ARTICLES}

1. Akšamović, D., Podnošenje pritužbi Europskoj komisiji radi povrede pravila tržišnog natjecanja, Novelties in Competition Law after the Accession of the Republic of Croatia to the European Union, Ekonomski fakultet Zagreb, Zagreb, 2014, pp. 136-157

2. Akšamović, D.; Vlaović, J., Fines in Croatian and European competition law, Journal of law and social sciences of the Law Faculty of University J. J. Strossmayer in Osijek, Vol. 33, Issue 2., 2017, pp. 47-76

3. Bolanča Kekez, Đ., Liability for damages for infringements of the competition law provisions, Zagreb, 2019, doctoral thesis

4. Derenčinović, D., Upravno-kaznene mjere zbog zlouporabe tržišta, Informator, No. 63166317,2014

5. Figueroa, Pablo, Fines and Antitrust Infringements under the New Spanish 2007 Competition Act, Vol. 5, Issue 1., 2009, pp. 39-45

6. Hillsman, Sally T., Fines and Day Fines, Crime and Justice: A Review of Research, Vol. 12, pp. $49-98$

7. Lister, Charles, Dawn Raids and Other Nightmare: The European Commission's Investigatory Powers in Competition Law Matters, Journal of Reprints for Antitrust Law and Economics, Vol. 22, Issues 1 and 2, 1993, pp. 523-532

8. Moens, G.; Trone, J., Commercial Law of the European Union, Dordrech, Springer, New York, 2010 
9. Petronijevic, Srdana; Soljaga, Zoran, Commitent Procedure under Serbian Competition Act, Yearbook of Antitrust and Regulatory Studies, Vol. 16, pp. 167-176

\section{EU LAW}

1. Directive (EU) 2019/1 of the European Parliament and of the Council of 11 December 2018 to empower the competition authorities of the Member States to be more effective enforcers and to ensure the proper functioning of the internal market (Text with EEA relevance.)

2. The Consolidated versions of the Treaty on European Union and the Treaty on the Functioning of the European Union (TFEU) [2016] OJ C326, 26/10/2012 P. 0001-0390

\section{LIST OF NATIONAL REGULATIONS}

1. The Act on the Amendments to Competition Act, Official Gazette No. 41/2021

2. The Competition Act, Official Gazette No. 79/09, 80/13, 41/21

\section{DECISIONS OF THE CROATIAN COMPETITION AGENCY}

1. Croatian Competition Agency against Pivovara Medvedgrad d.o.o., Zagreb, No. UP/I 03403/2020-03/003

2. Croatian Competition Agency against Prvo hrvatsko pivo 1664 d.o.o., Zagreb, No. UP/I 034-03/2020-03/004

3. Croatian Competition Agency against Osječka pivovara d.d., Osijek, No. UP/I 03403/2020-03/001

4. Croatian Competition Agency against Maca LM d.o.o., Zagreb and Radio Trsat d.o.o., Rijeka, No. UP/I 034-03/2018-02/015

5. Croatian Competition Agency against Extra FM d.o.o. Zagreb and HIT FM d.o.o. Zagreb (now Extra FM Zagreb d.o.o. ), No. UP/I 034-03/2018-02/005

6. Croatian Competition Agency against Teramedia d.o.o., Zagreb and Nezavisna Televizija d.o.o., Zagreb, No. UP/I 034-03/2017-02/014

7. Croatian Competition Agency against Josip Živković, owner of „Jole“, Bilice, No. UP/I 034-03/2017-03/001

8. Croatian Competition Agency against Ivan Jurić-Kaćunić and Radio Enter, Zagreb and Radio Dalmacija, Split, No. UP/I 034-03/2017-02/003

9. Croatian Competition Agency against Katijan Knok and Uma FM, Zagreb and Radio Croatia, Zagreb, No. UP/I 034-03/2017-02/007

10. Croatian Competition Agency against Hrvoje Barišić and Antena FM, Zagreb and Obiteljski radio, Zagreb, No. UP/I 034-03/2017-02/008

11. Croatian Competition Agency against Tahia FM d.o.o., Zagreb and Radio Croatia d.o.o., Zagreb, No. UP/I 034-03/2016-02/002

12. Croatian Competition Agency against Uma FM d.o.o., Zagreb and Radio Croatia d.o.o., Zagreb, No. UP/I 034-03/2016-02/004 
13. Croatian Competition Agency against Antena FM d.o.o., Zagreb and Obiteljski radio d.o.o., Zagreb, No. UP/I 034-03/2016-02/003

14. Croatian Competition Agency against Mile Kaselj, Đakovo and Novi radio d.o.o., Đakovo, No. UP/I 034-03/2015-02/008

15. Croatian Competition Agency against CAPITAL FM d.o.o., Zagreb and Janus d.o.o., Osijek; and Radio Velika Gorica d.o.o., Velika Gorica, No. UP/I 034-03/2015-02/006

16. Croatian Competition Agency againts Radio Trsat, No. UP/I 034-03/2014-02/009

17. Croatian Competition Agency against NCP d.o.o., Šibenik / Županijski radio Šibenik d.o.o., Šibenik, No. UP/I 034-03/2014-02/008

18. Croatian Competition Agency against Totalni radio d.o.o., Zagreb, No. UP/I 034-03/201403/004

19. Croatian Competition Agency against Expres radio d.o.o., Zagreb, No. UP/I 034-03/201403/003

20. Croatian Competition Agency against Ivan Obad, owner of „Auto Obad“ servis, Zagreb repair, maintenance and resale, No. UP/I 034-03/2014-03/001

21. Croatian Competition Agency against The Croatian Composers Society - Copyright Music Rights Protection, HDS-ZAMP, Zagreb, No. UP/I 034-03/2013-03/005

22. Croatian Competition Agency against Mercator - H d.o.o., Sesvete, No. UP/I 034-03/201303/006

23. Croatian Competition Agency against Kmag d.o.o., Gornji Stupnik, No. UP/I 03403/2012-03/004

\section{WEBSITE REFERENCES}

1. About us, http://www.aztn.hr/en/about-us/, Accessed 10 April 2021

2. Cases, https://www.aztn.hr/en/cases/, Accessed 15 January 2021

3. Banknotes, https://www.hnb.hr/en/currency/banknotes, 11 April 2021 